\title{
Fauna of mosquitoes (Diptera: Culicidae) in Goytacazes National Forest and surrounding area, State of Espírito Santo, Southeastern Brazil
}

\author{
Thieres Marassati das Virgens $^{1^{*}}$, Helder Ricas Rezende ${ }^{2}$, Israel Souza Pinto ${ }^{3}$ \& Aloísio Falqueto $^{3}$ \\ ${ }^{1}$ Instituto Federal do Espírito Santo, Av. Filogônio Peixoto 2220, Bairro Aviso, CEP 29901-291, Linhares, ES, Brazil \\ ${ }^{2}$ Secretaria de Estado da Saúde, Núcleo de Entomologia e Malacologia do Espírito Santo, \\ Rua Pedro Zangrande 320, CEP 29164-020 Serra, ES, Brazil \\ ${ }^{3}$ Universidade Federal do Espírito Santo, Departamento de Patologia, Unidade de Medicina Tropical Vitória, \\ Av. Marechal Campos 1468, Maruípe, CEP 29043-900 - ES, Brazil \\ *Corresponding author: Thieres Marassati Virgens, e-mail: thieresv@ifes.edu.br
}

VIRGENS, T. M., REZENDE, H.R., PINTO, I.S., FALQUETO, A. Fauna of mosquitoes (Diptera: Culicidae) in Goytacazes National Forest and surrounding area, state of Espírito Santo, southeastern Brazil. Biota Neotropica. 18(1): e20160250. http://dx.doi.org/10.1590/1676-0611-BN-2016-0250

\begin{abstract}
Mosquitoes comprehend a group with a major impact on public health, because some species transmit parasites vertebrate hosts. Comparative studies between preserved environment and disturbed areas provide important epidemiological information, due to the major knowledge on species populational dynamics and the possibility of a contact between vector species and human population. This work aims to characterize and compare the fauna of mosquitoes in the Goytacazes National Forest (GNF) and surrounding area, in the State of Espírito Santo, in Brazil. Collections occurred simultaneously in a preserved environment and in a peridomicile, from 15:00 to 18:00, between July 2008 and May 2009. In each environment, it was used a modified trap of Shannon type. As a result, 1,490 specimens from 14 genera and 19 identified species were collected. The species diversity $(H=1.95)$, species richness $(S=17)$, equitability index $(\mathrm{J}=0.68)$ and the number of collected specimens $(\mathrm{n}=1,100)$ were higher in the forest environment. The plentiful species were respectively Aedes (Ochlerotatus) scapularis (Rondani, 1848), Culex (Culex) nigripalpus Theobald, 1901 and Aedes (Ochlerotatus) fulvus (Wiedemann, 1828). Our results demonstrate that the occurrence of vector species in this region increases the potential risk of diverse arboviruses occurrence, especially wild-type yellow fever.
\end{abstract}

Keywords: Atlantic Forest, Disease Vector, Diversity, Richness, Yellow Fever.

\section{Fauna de mosquitos (Diptera: Culicidae) na Floresta Nacional de Goytacazes e área adjacente, estado do Espírito Santo, sudeste do Brasil}

Resumo: Os mosquitos compreendem um grupo importante para a saúde pública, porque algumas espécies estão envolvidas na transmissão de várias doenças para os seres humanos. Estudos comparativos entre ambiente florestal e áreas perturbadas fornecem importantes informações epidemiológicas, dado o maior conhecimento da dinâmica populacional das espécies e a possibilidade de contato entre as espécies de vetores e população humana. O objetivo deste estudo foi caracterizar e comparar a fauna de mosquitos na Floresta Nacional de Goytacazes e área adjacente, no estado do Espírito Santo, Brasil. As coletas ocorreram simultaneamente no ambiente florestal e peridomicílio, de 15:00 às 18:00 horas, entre junho de 2008 e maio de 2009. Em cada ambiente foi utilizada uma armadilha do tipo Shannon modificada. Como resultado, foram coletados 1.490 espécimes pertencentes a 14 gêneros e 19 espécies identificadas. A diversidade de espécies $(H=1,95)$, riqueza de espécies $(S=17)$, índice de equitabilidade $(J=0,68)$ e o número de espécimes coletados $(\mathrm{n}=1.100)$ foram maiores no ambiente florestal. As espécies mais abundantes foram respectivamente Aedes (Ochlerotatus) scapularis (Rondani, 1848), Culex (Culex) nigripalpus Theobald, 1901 and Aedes (Ochlerotatus) fulvus (Wiedemann, 1828). Os resultados demonstram que a ocorrência de espécies vetores na região, aumenta o risco potencial de ocorrência de diversas arboviroses, com destaque para a febre amarela silvestre.

Palavras-chave: Mata Atlântica, Vetores de doenças, Diversidade, Riqueza, Febre Amarela.

\section{Introduction}

The Atlantic Forest is one of the world's biodiversity hotspots (Myers et al. 2000, Orme et al. 2005). The environmental degradation suffered by this biome has caused changes in the natural landscape, with consequent alteration of the fauna and population dynamics of different living organisms, including insects such as mosquitoes and sandflies (Virgens et al. 2008, 2015).

Mosquitoes (Diptera: Culicidae) consist of a group with high impact to public health, because some species are involved in the transmission of 
pathogens responsible for human diseases, such as dengue, zika, chikungunya, yellow fever, filariasis and malaria (Consoli \& Lourenço-de-Oliveira 1994, Forattini 2002, Wilkerson et al. 2015). The association between mosquitoes and these diseases has stimulated researches on the fauna, geographic distribution and ecology of these insects, especially in areas with potential risk of pathogen transmission.

In the State of Espírito Santo, the few existing studies on the fauna characterization and diversity of mosquitoes are directed to Anophelinae subfamily and areas of potential risk of malaria (Andrade \& Brandão 1957, Deane et al. 1968, Natal et al. 2007, Meneguzzi et al. 2009, Rezende et al. 2009a, b, 2013, Silva et al. 2013). In the mountainous region of Espírito Santo, where sporadic cases of malaria are notified, studies have incriminated Anopheles (Kerteszia) cruzii Dyar \& Knab, 1908 as the main vector of Plasmodium vivax (Grassi $\&$ Feletti, 1890) (Rezende et al. 2009b, 2013). In the flat region, it is possible incriminating Anopheles (Nyssorhynchus) darling Root, 1926 as a vector in imported malaria cases (Meneguzzi et al. 2009, Silva et al. 2013). In addition, there are several areas with potential occurrence of $A n$. (Nys.) darlingi in the State of Espírito Santo, which deserve additional studies to understand the Anopheles Meigen, 1818 fauna (Meneguzzi et al. 2009).

Regarding Culicinae subfamily, studies mainly have focus in Aedes (Stegomyia) aegypti (Linnaeus, 1762) (Varejão et al. 2005, Mendonça et al. 2011, Santos et al. 2011) and the knowledge on the occurrence of species belonging to this subfamily in wild environment is scarce (Deane et al. 1968, Alencar et al. 2004, Rezende et al. 2011). Therefore, studies on the Culicidae fauna in Espírito Santo wild areas, mainly in flat areas, should be encouraged.

Considering the epidemiological importance of mosquitoes (Diptera: Culicidae) and the lack of invertigations in the region, this study aims to characterize and compare the diurnal fauna of mosquitoes in the Goytacazes National Forest (GNF) and surrounding area, in the State of Espírito Santo, Brazil.

\section{Material and Methods}

\section{Study Area}

Samples in two ecologically distinct environments were collected: 1) forest environment represented by the GNF and 2) GNF adjacent anthropic environment, represented by peridomicile occupied in general by cocoa crops grown in cabruca agroforest system, where cacao trees are planted under thinned-out native forests, and presenting human habitations with the presence of attached livestock (pigsty, chicken coop and barn).

The GNF ( $19^{\circ} 28^{\prime} 01^{\prime}$ ' S; $40^{\circ} 04^{\prime} 18^{\prime \prime} \mathrm{W}$; elevation of 10 meters [a.s.1]) is a unit of federal conservation, linked to the Chico Mendes Institute for Biodiversity Conservation, which granted permission to carry out this research. The GNF is located in Linhares, Espírito Santo, Southeast Brazil (Figure 1). It has an estimated area of 1,423 hectares located between the Doce River and the Federal Highway BR 101, lying about 1 kilometer from Linhares downtown.

The GNF is located about $30 \mathrm{~km}$ from the Vale Natural Reserve and $50 \mathrm{~km}$ from the Sooretama Biological Reserve, representing the last remaining Atlantic Forest of the Doce river alluvial floodplain (Rolim et al. 2006). The region has a tropical monsoon climate, according to KöppenGeiger's climatic classification (Peel et al. 2007). Average temperatures range from 11 to $18^{\circ} \mathrm{C}$ in the coldest months (June to August) and $30-34^{\circ} \mathrm{C}$ in the warmer months (December to March), with about 1,200 $\mathrm{mm}$ of annual rainfall (Hijmans et al. 2005).

\section{Sampling}

The collections simultaneously occurred in the forest and in the peridomicile, between June 2008 and May 2009. In each environment, it was used a modified Shannon trap (Shannon, 1939), of dimensions

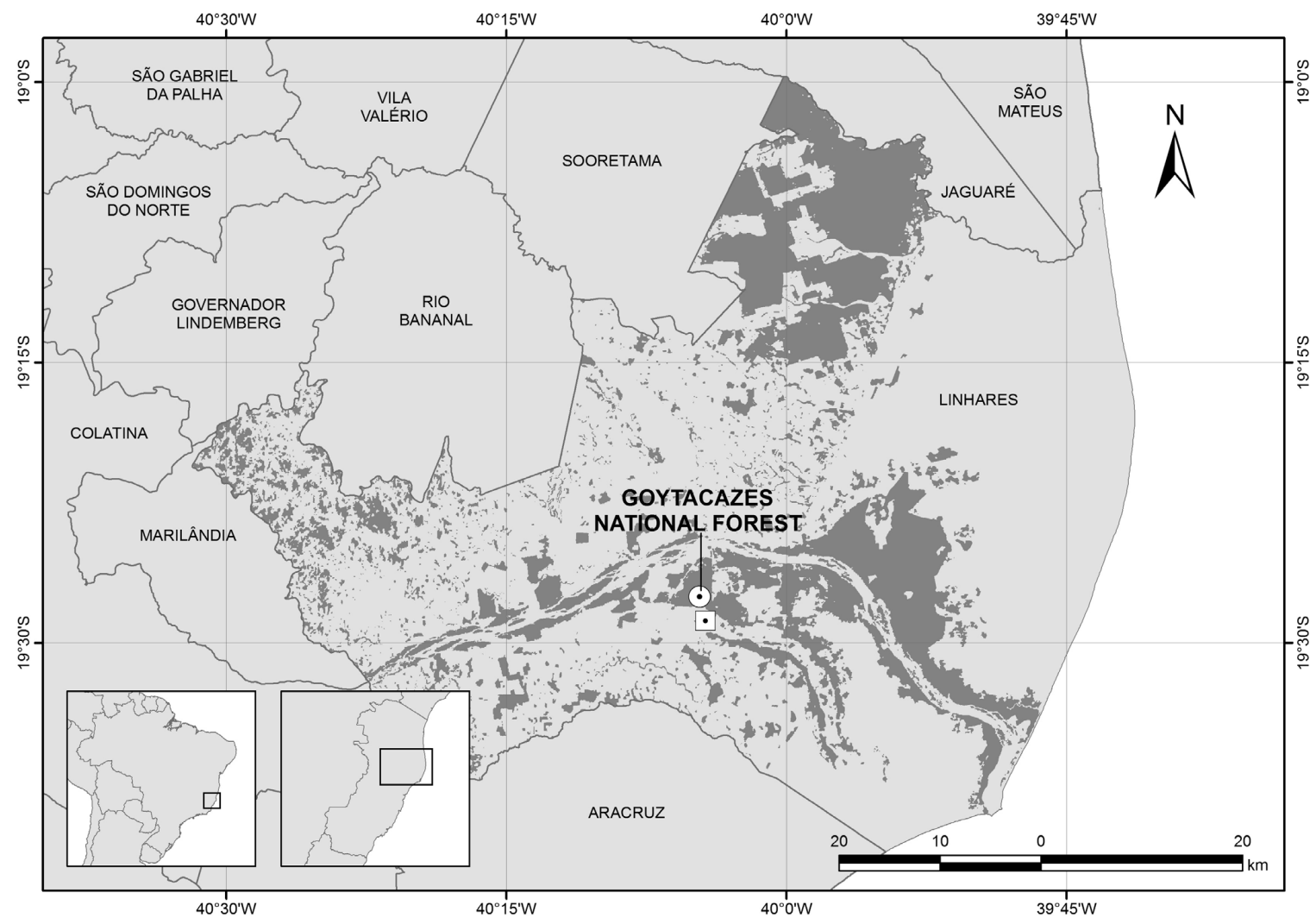

Figure 1. Collection sites (square - peridomiciliary environment; circle - forest environment represented of the Goytacazes National Forest) in the Atlantic Forest, State of Espírito Santo, Southeastern Brazil. 
$1 \mathrm{~m} \mathrm{X} 1 \mathrm{~m} \mathrm{X} 1.9 \mathrm{~m}$ (topped with an overhanging square roof of side $1.6 \mathrm{~m}$ ) (Ferreira et al. 2001). The culicids were collected using a Castro manual suction catcher and tubes impregnated with ethyl acetate. These samples were collected once (one day) a month, from 15:00 to 18:00, with a total exposure of 36 hours in each environment.

The collected specimens were sent to the Parasitology Laboratory at the Federal University of Espírito Santo (UFES), and the morphological identification followed the taxonomic criteria proposed by Consoli \& Lourenço-de-Oliveira (1994), Forattini (2002), and Marcondes (2011). The abbreviations of genera and subgenera followed Reinert (2001). A sample of the collected material was sent to the Entomology Laboratory at the Public Health School of the University of São Paulo, to confirm the species identification. Lastly, we have deposited the collected material in the entomological collection of Tropical Medicine Unit at UFES.

\section{Climatic data}

Climate precipitation data $\left(\mathrm{mm}^{3}\right)$, average temperature $\left({ }^{\circ} \mathrm{C}\right)$ and relative humidity (\%) were obtained from the National Institute of Meteorology Station, located in the Capixaba Institute of Research, Technical Assistance and Rural Extension (INCAPER), in Linhares, about 8 kilometers of distance from the studied area.

\section{Statistical analysis}

The specific richness (S), evenness indexes (J), and Shannon diversity indexes $(\mathrm{H})$ were evaluated for each environment using PAST 2.09 software (Hammer et al. 2001). In addition, it was used a Biostat 5.0 software to evaluate the difference between the number of specimens collected in both environments by Mann-Whitney statistical test and the association between the climate data and the most abundant species in each environment by Spearman nonparametric test. Differences were considered significant when the probability $(p)$ of error was less than $5 \%(p<0.05)$. It was only performed the analysis with specimens identified into specific level.

\section{Results}

A total of 1,490 culicids were collected $(S=20, J=0.58, H=1.74)$, in which 1,483 specimens $(99.5 \%)$ belonging to the subfamily Culicinae and seven specimens $(0.5 \%)$ belonging to the subfamily Anophelinae. The Aedini and Sabethini tribes represented $76.0 \%$ of the total, with 604 and 529 specimens, respectively (Table 1). The most abundant genera were Aedes Meigen, 1818 (37.1\%), Trichoprosopon Theobald, 1901 (28.0\%) and Culex Linnaeus, 1758 (17.2\%). These collected specimens belong to 14 genera and 19 identified species (Table 1).

The most abundant species were Aedes (Ochlerotatus) scapularis (Rondani, 1848), with 408 specimens (27.3\%), Culex (Culex) nigripalpus Theobald, 1901 with 230 specimens (15.4\%), and Aedes (Ochlerotatus) fulvus (Wiedemann, 1828), with 123 specimens (8.2\%). Aedes (Ochlerotatus) scapularis and Cx. (Cux.) nigripalpus were the most abundant species in both studied environments and there was no significant difference in the numbers of specimens between these two environments. The species diversity $(H=1.95)$, species richness $(S=17)$, equitability index $(J=0.68)$ and the number of collected specimens $(n=1,100)$ were higher in the forest environment.

The species, Aedes (Ochlerotatus) taeniorhynchus (Wiedemann, 1821), Anopheles (Nyssorhynchus) evansae (Brèthes, 1926), Haemagogus capricornii/janthinomys, Haemagogus (Conopostegus) leucocelaenus (Dyar \& Shannon, 1924), Psorophora (Janthinosoma) ferox (Humboldt, 1819) and Trichoprosopon digitatum (Rondani, 1848) were collected exclusively in the forest environment, while Anopheles (Nyssorhynchus) albitarsis Lynch-Arribalzaga, 1878, Anopheles (Nyssorhynchus) argyritarsis Robineau-Desvoidy, 1827, Coquillettidia (Rhynchotaenia) chrysonotum (Peryassú, 1922), Coquillettidia (Rhynchotaenia) venezuelensis (Theobald, 1912) and Mansonia (Mansonia) humeralis Dyar \& Knab, 1916 were collected only in the peridomicile.

In the forest environment, Ae. (Och.) scapularis showed a positive and significant correlation with the monthly precipitation $(\mathrm{R}=0.84 ; \mathrm{P}=0.00)$ and monthly average temperature $(\mathrm{R}=0.62 ; \mathrm{P}=0.02)$. In the peridomicile,

Table 1. Number of mosquitoes (Diptera, Culicidae) collected in Shannon traps between June 2008 to May 2009 and ecological indices from two environments (F = Forest; $\mathrm{P}=$ Peridomicile) at Goytacazes National Forest, municipality of Linhares, State of Espírito Santo, southeastern Brazil. $(\mathrm{T}=$ Total)

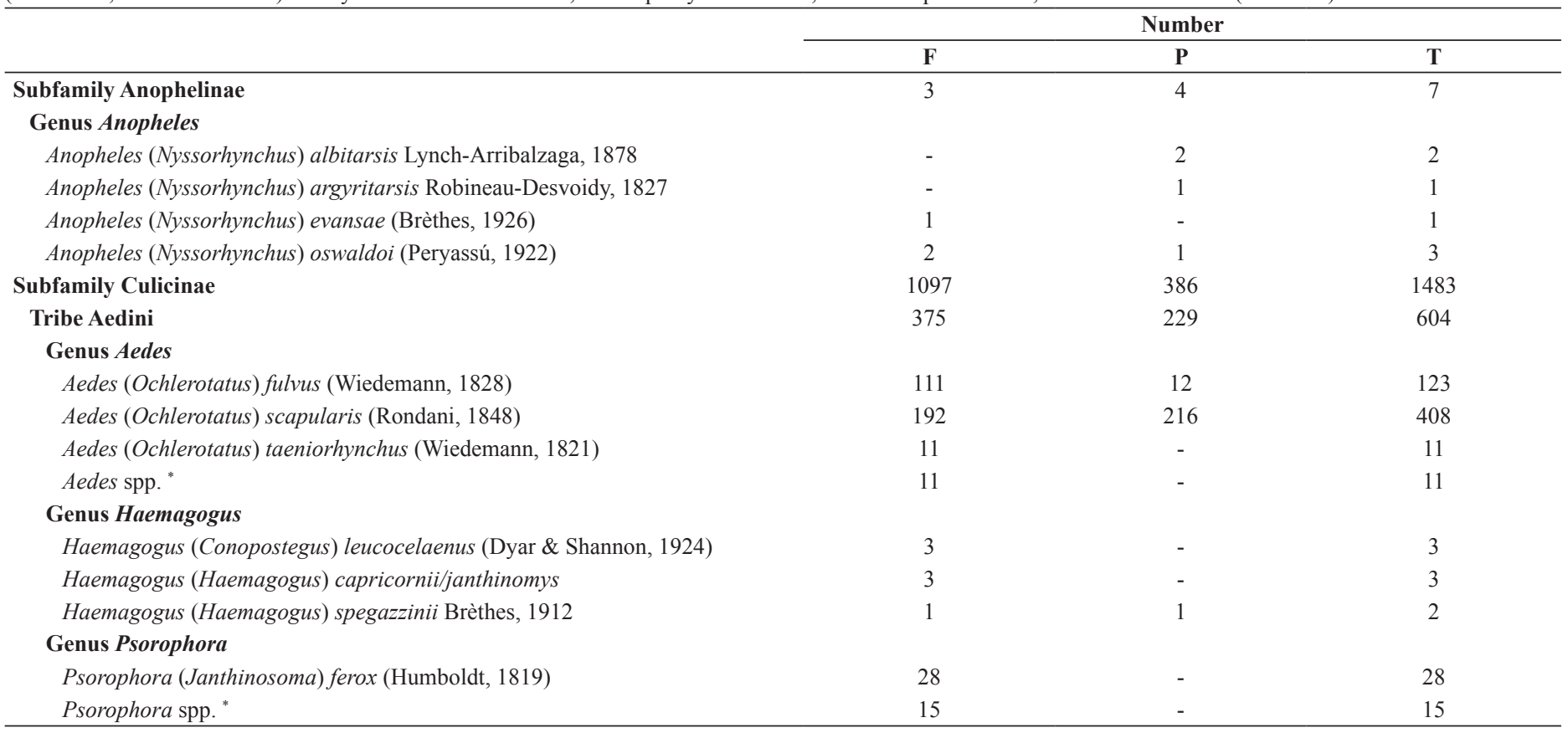

\footnotetext{
* Refers to damaged specimens, not being possible identified to species level.
} 
Virgens, T.M. et al.

Table 1. Continued..

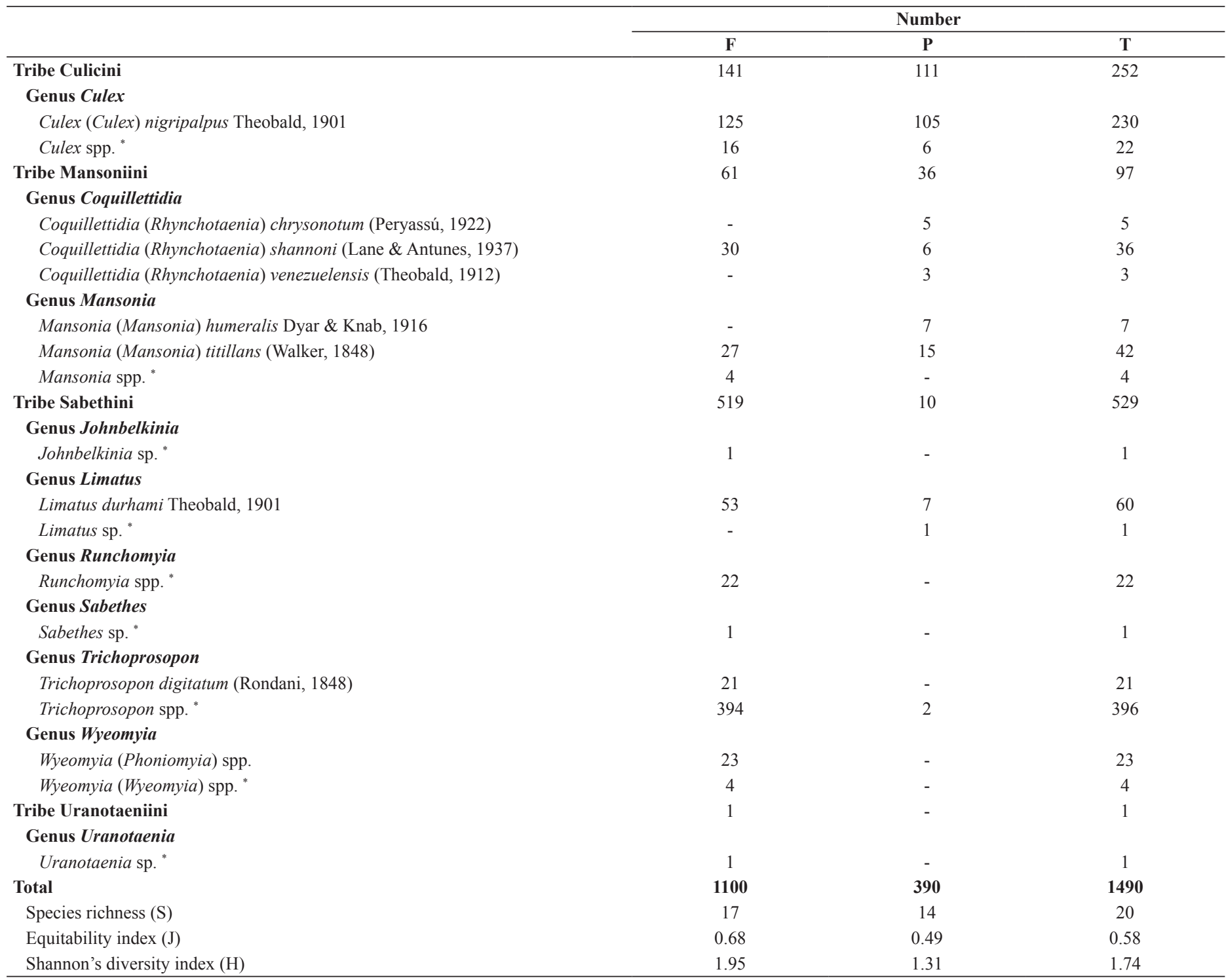

* Refers to damaged specimens, not being possible identified to species level.

Ae. (Och.) scapularis showed a positive and significant correlation with monthly rainfall $(\mathrm{R}=0.68 ; \mathrm{P}=0.01)$, and $C x$. $(C u x$. $)$ nigripalpus showed a positive and significant correlation with relative humidity $(\mathrm{R}=0.88$; $\mathrm{P}=0.00)$. Results were not significant in other analysis of Ae. $(O c h$. scapularis, Cx. (Cux.) nigripalpus, and climate data.

\section{Discussion}

The culicides fauna observed in the forest environment presented a composition of bioindicators of anthropogenic areas, represented by Ae. (Och.) scapularis and the Tribe Mansoniini species (Dorvillé 1996, Guimarães et al. 2000, Cardoso et al. 2011), indicating that the area presents a significant degree of environmental degradation, despite being a unit of Atlantic Forest Federal Conservation.

The number of specimens of Anophelinae subfamily collected in this study was relatively low. However, the occurrence of An. (Nys.) albitarsis s.l., An. (Nys.) evansae and Anopheles (Nyssorhynchus) oswaldoi (Peryassú, 1922), even in low frequency, presents epidemiological importance, due to the potential transmission of malaria by these species (Consoli \& Lourenço-de-Oliveira 1994, Forattini 2002). Silva et al. (2013), in a study conducted in Sooretama Biological Reserve, in the State of Espírito Santo, incriminated An. (Nys.) darlingi as a primary vector and An. (Nys.) albitarsis s.l. as a secondary vector of malaria in the region. Thus, the region has characteristics compatible with the re-emergence of malaria, especially considering that the area has a potential risk of disease transmission due to the occurrence of An. (Nys.) darlingi (Meneguzzi et al. 2009).

In relation to Culicinae subfamily, genera Aedes, Trichoprosopon and Culex were the most abundant, respectively. Several species of Aedes and Culex have epidemiological importance, once we can incriminate them in the transmission of pathogens to humans and other animals (Consoli \& Lourenço-de-Oliveira 1994, Forattini 2002).

The three most abundant species observed in this study were Ae. (Och.) scapularis, Cx. (Cux.) nigripalpus and Ae. (Och.) fulvus. Cardoso et al. (2011) also observed the abundance of Ae. (Och.) scapularis and Cx. (Cux.) nigripalpus in the Atlantic Forest from the State of Rio Grande do Sul. 
Aedes (Ochlerotatus) scapularis was the most abundant species in the study area, and its occurrence in both environments seems to indicate that this species has a higher degree of eclecticism in relation to their eating habits, since it presents compatibility with both artificial and natural breeding (Forattini 2002). In this context, it performs blood meal in peridomicile and in the altered areas, and then it returns to the adjacent Atlantic Forest, a place that serves as a shelter (Consoli \& Lourenço-de-Oliveira 1994, Forattini 2002). The species has vector competence for the transmission of several arboviruses, such as Ilhéus virus, Rocio virus and the yellow fever virus (Forattini 2002, Wilkerson et al. 2015). It also presented a positive and significant correlation with the monthly rainfall in both studied environments, which demonstrates that rain influences directly and positively in its density.

Culex (Culex) nigripalpus was the second most abundant species, presenting no significant differences in the number of collected specimens among the studied environment. This result can be explained by the presence of chickens in peridomicile and high diversity of birds in the GNF, once Cx. (Cux.) nigripalpus has an ornitophilic behavior (Guimarães et al. 1987, Consoli \& Lourenço-de-Oliveira 1994, Forattini 2002). In this context, the mosquito has a potential for transmission of some arboviruses, even if we consider its low anthropophily (Laporta et al. 2008, Cardoso et al. 2011).

Aedes (Ochlerotatus) fulvus represented the third most abundant species, being mainly collected in the forest environment. This is an essentially wild species and possibly presents an association with the transmission of arboviruses, including yellow fever (Consoli \& Lourenço-de-Oliveira 1994, Forattini 2002, Fé et al. 2003).

Regarding Haemagogus spp., it was registered a low number of specimens. However, the occurrence of Hg. (Con.) leucocelaenus and Haemagogus (Haemagogus) spegazzinii Brèthes, 1912 has a higher epidemiological importance, due to its involvement with the transmission of wild-type yellow fever (Forattini 2002, Vasconcelos et al. 2003). Rezende et al. (2011) reported the occurrence of Hg. (Con.) leucocelaenus colonizing artificial container (sectioned tire) in the same study area of our research.

Aedes (Ochlerotatus) taeniorhynchus is a common species in tide-affected areas, where its immatures develop in brackish water (Forattini 2002). Marcondes et al. (2012) collected winged specimens to evaluate the differences on eggs kinds in Vitória, Espírito Santo. The species has high flight capacity. However, the species occurrence in the study area, distant about $40 \mathrm{~km}$ from the Atlantic Ocean, appears to be associated with breeding present in the area, which have fluid collections with some degree of salinity.

The data obtained in this study show that the occurrence of vector species in the region increases the potential risk of several arboviruses, mainly due to the occurrence of Ae. (Och.) scapularis, Ae. (Och.) fulvus, Hg. (Con.) leucocelaenus and $\mathrm{Hg}$. (Hag.) spegazzinii, species incriminated as vectors of wild-type yellow fever etiological agents. These results demonstrate a need for further entomological studies on bio-ecological aspects of local fauna, including the possible spread to the anthropic environment.

\section{Acknowledgments}

We thank the head of the Goytacazes National Forest, Leony Wand Del Rey de Oliveira, for the authorization for collecting the biological material and the logistical support on this research. We also thank the Federal Institute of Espírito Santo (Ifes), for the financial support provided to this article translation, and Sandra Mara M. S. Bassani for the English review of this article.

\section{Author Contributions}

T. M. Virgens, I. S. Pinto and H. R. Rezende were responsible for conception, field work, data analysis, identification of specimens and the writing manuscript. A. Falqueto coordinated the study and final editing of the manuscript.

\section{Conflicts of interest}

The authors declare that they have no conflict of interest related to the publication of this manuscript.

\section{References}

ALENCAR, J., GIL-SANTANA, H.R., LOPES, C.M., SANTOS, J.S. \& GUIMÃRAES A.E. 2004. Utilização de armadilha "ovitrampa" para monitoramento de Haemagogus janthinomys (Diptera, Culicidae) em área de mata Atlântica. Entomol. Vect. 11 (2): 369-374.

ANDRADE, R.M. \& BRANDÃO, H. 1957. Contribuição para o conhecimento da fauna de anofelinos do estado do Espírito Santo: área de distribuição e incidência das espécies por cidades, vilas e povoados. Rev. Bras. Malariol. Doenças Trop. 9: 391-403.

CARDOSO, J.C., PAULA, M.B., FERNANDES, A., SANTOS, E., ALMEIDA, M.A.B., FONSECA, D.F., \& SALLUM, M.A.M. 2011. Ecological aspects of mosquitoes (Diptera: Culicidae) in an Atlantic forest area on the north coast of Rio Grande do Sul State, Brazil. J. Vector Ecol. 36 (1): 175-186.

CONSOLI, R.A.G.B. \& LOURENÇO-DE-OLIVEIRA, R. 1994. Principais mosquitos de importância sanitária no Brasil. Editora FIOCRUZ, Rio de Janeiro.

DEANE, L.M., FERREIRA NETO, J.A. \& SITÔNIO, J.G. 1968. Estudos sobre a malária no Estado do Espírito Santo. Rev. Brasil. Biol. 28(4): 531-536.

DORVILLÉ, L.F.M. 1996. Mosquitoes as bioindicators of forest degradation in Southeastern Brazil, a statistical evaluation of published data in the literature. Studies Neotrop. Fauna Environ. 31(2): 68-78.

FÉ, N.F., BARBOSA, M.G.V., FÉ, F.A.A., GUERRA, M.V.F. \& ALECRIM, W.D. 2003. Fauna de Culicidae em municípios da zona rural do Estado do Amazonas, com incidência de febre amarela. Rev. Soc. Bras. Med. Trop. 36(3): 343-348.

FERREIRA, A.L., SESSA, P.A., VAREJÃO, J.B.M. \& FALQUETO, A. 2001. Distribution of sand flies (Diptera: Psychodidae) at different altitudes in an endemic region of American cutaneous leishmaniasis in the State of Espírito Santo, Brazil. Mem. Inst. Oswaldo Cruz 96(8): 1061-1067.

FORATTINI, O.P. 2002. Culicidologia Médica. Ed. Edusp. São Paulo, v.2.

GUIMARÃES, A.E., ARLÉ, M. \& MACHADO, R.M.N. 1987. Mosquitos no Parque Nacional da Serra dos Órgãos, estado do Rio de Janeiro, Brasil. IV. Preferência alimentar. Mem. Inst. Oswaldo Cruz 82(2): 277-285.

GUIMARÃES, A.E., GENTILE, C., LOPES, C.M. \& MELLO, R.P. 2000. Ecology of mosquitoes (Diptera: Culicidae) in areas of Serra do Mar State Park, State of São Paulo, Brazil. II- Habitat Distribution. Mem. Inst. Oswaldo Cruz 95(1): 17-28.

HAMMER, Ø., HARPER, D.A.T. \& RYAN, P.D. 2001. PAST: Paleontological statistics software package for education and data analysis. Palaentol. Electronica 4:9pp.

HIJMANS, R.J., CAMERON, S.E., PARRA, J.L., JONES, P.G. \& JARVIS, A. 2005. Very high resolution interpolated climate surfaces for global land areas. Int. J. Climatol. 25(15): 1965-1978.

LAPORTA, G.Z., CRIVELARO, T.B., VICENTIN, E.C., AMARO, P., BRANQUINHO, M.S. \& SALLUM, M.A.M. 2008. Culex nigripalpus Theobald (Diptera, Culicidae) feeding habit at the Parque Ecológico do Tietê, São Paulo, Brazil. Rev. Bras. Entomol. 52(4): 663-668.

MARCONDES, C.B. 2011. Entomologia Médica e Veterinária. Editora Atheneu. São Paulo.

MARCONDES, C.B., MÜLLER, G.A., SANTOS-MALLET, J., ALENCAR, J., SARMENTO, J.S., SANTOS, C.B. \& REZENDE, H.R. 2012. Scanning electron microscopy of eggs of Ochlerotatus taeniorhynchus (Diptera: Culicidae, Aedini). Zootaxa 3509: 77-80.

MENDONÇA, H.F.M.S., FERREIRA, A.L., SANTOS, C.B., REZENDE, H.R., FERREIRA, G.E.M., LEITE, G.R. \&. FALQUETO, A. 2011. Breeding sites of Aedes aegypti in metropolitan vacant lots in Greater Vitória, State of Espírito Santo, Brazil. Rev. Soc. Bras. Med. Trop. 44 (2): 243-246.

MENEGUZZI, V.C., SANTOS, C.B., PINTO, I.S., FEITOZA, L.R., FEITOZA, H.N. \& FALQUETO, A. 2009. Use of geoprocessing to define malaria risk areas and evaluation of the vectorial importance of anopheline mosquitoes (Diptera: Culicidae) in Espírito Santo, Brazil. Mem. Inst. Oswaldo Cruz 104(4): 570-575. 
MYERS, N., MITTERMEIER, R.A., MITTERMEIER, C.G., FONSECA, G.A.B. \& KENT, J. 2000. Biodiversity hotspots for conservation priorities. Nature 403(6772): 853-858.

NATAL, D., URBINATTI, P.R., MALAFRONTE, R.S., REZENDE, H.R, CERUTTI JR, C. \& SALLUM, M.A.M. 2007. First record of Anopheles (Anopheles) costai Fonseca \& Ramos, 1939 in Espírito Santo State, Brazil. Rev. Inst. Med. Trop. S. Paulo 49(5): 323-326.

ORME, C. D. L., DAVIES, R.G., BURGESS, M., EIGENBROD, F., PICKUP, N., OLSON, V.A., WEBSTER, A.J., TZUNG-SU, D., RASMUSSEN, P.C., RIDGELY, R.S., STATTERSFIELD, A.J., BENNETT, P.M., BLACKBURN, T.M., GASTON, K.J. \& OWENS, I.P.F. 2005. Global hotspots of species richness are not congruent with endemism or threat. Nature 436(7056): 1016-1019.

PEEL, M.C., FINLAYSON, B.L. \& MCMAHON, T.A. 2007. Updated world map of the Köppen-Geiger climate classification. Hydrol. Earth Syst. Sci. 11(5): 1633-1644.

REINERT, JF. 2001. Revised list of abbreviatios for genera and subgenera of Culicidae (Diptera) and notes on generic and subgeneric changes. J. Am. Mosq. Control. Assoc. 17(1): 51-55.

REZENDE, H.R., SESSA, P.A., FERREIRA, A.L., SANTOS, C.B., LEITE, G.R. \& FALQUETO, A. 2009a. Efeitos da implantação da Usina Hidrelétrica de Rosal, Rio Itabapoana, Estados do Espírito Santo e Rio de Janeiro, sobre anofelinos, planorbídeos e flebotomíneos. Rev. Soc. Bras. Med. Trop. 42(2): 160-164.

REZENDE, H.R., SOARES, R.M., CERUTTI JR, C., ALVES, I.C., NATAL, D., URBINATTI, P.R., YAMASAKI, T., FALQUETO, A. \& MALAFRONTE, R.S. 2009b. Entomological characterization and natural infection of Anophelines in an area of the Atlantic Forest with autochthonous malaria cases in mountainous region of Espírito Santo State, Brazil. Neotrop. Entomol. 38(2): 272-280.

REZENDE, H.R., VIRGENS, T.M., LIBERATO, M.A., VALENTE, F.I., FERNANDES, A. \& URBINATTI, P.R. 2011. Aspectos ecológicos de culicídeos imaturos em larvitrampas de floresta e ambiente antrópico adjacente no município de Linhares, ES, Brasil. Epidemiol. Serv. Saúde, 20(3): 385-391.

REZENDE, H.R., FALQUETO, A., URBINATTI, P.R., MENEZES, R.M.T., NATAL, D. \& CERUTTI JR, C. 2013. Comparative study of distribution of Anopheline vectors (Diptera: Culicidae) in areas with and without malaria transmission in the highlands of an extra-amazonian region in Brazil. J. Med. Entomol. 50(3): 598-602.

ROLIM, S.G., IVANAUSKAS, N.M., RODRIGUES, R.R., NASCIMENTO, M.T., GOMES, J.M.L., FOLLI, D.A. \& COUTO, H.T.Z. 2006. Composição Florística do estrato arbóreo da floresta estacional semidecidual na planície aluvial do rio Doce, Linhares, ES, Brasil. Acta Bot. Bras. 20(3): 549-561.

SANTOS, C.B., LEITE G.R. \& FALQUETO, A. 2011. Does native bromeliads represent important breeding sites for Aedes aegypti (L.) (Diptera: Culicidae) in urbanized areas? Neotrop. Entomol. 40(2): 278-281.

SHANNON, R. 1939. Methods for collecting and feeding mosquitos in jungle yellow fever studies. Amer. J. Trop. Med. 19: 131-140.

SILVA, K.S., PINTO, I.S., LEITE, G.R., VIRGENS, T.M., SANTOS, C.B. \& FALQUETO, A. 2013. Ecology of Anopheline Mosquitoes (Diptera: Culicidae) in Central Atlantic Forest Biodiversity Corridor, Southeastern Brazil. J. Med. Entomol. 50(1): 24-30.

VAREJÃO, J.B.M., SANTOS, C.B., REZENDE, H.R., BEVILACQUA, L.C. \& FALQUETO, A. 2005. Criadouros de Aedes (Stegomyia) aegypti (Linnaeus, 1762) em bromélias nativas na Cidade de Vitória, ES. Rev. Soc. Bras. Med. Trop. 38(3): 238-240.

VASCONCELOS, P.F.C., SPERB, A.F., MONTEIRO, H.A.O., TORRES, M.A.N., SOUSA, M.R.S., VASCONCELOS, H.B., MARDINI, L.B.L.F. \& RODRIGUES, S.G. 2003. Isolations of yellow fever virus from Haemagogus leucocelaenus in Rio Grande do Sul State, Brazil. Trans. R. Soc.Trop. Med. Hyg. 97(1): 60-62.

VIRGENS, T.M., SANTOS, C.B., PINTO, I.S., SILVA, K.S., LEAL, F.C. \& FALQUETO, A. 2008. Phlebotomine sand flies (Diptera, Psychodidae) in an American tegumentary leishmaniasis transmission area in northern Espírito Santo state, Brazil. Cad. Saúde Públ. 24(12): 2969-2978.

VIRGENS, T.M., REZENDE, H.R., PINTO, I.S. \& FALQUETO, A. 2015. Sand fly fauna (Diptera, Psychodidae) from the Goytacazes National Forest and surrounding areas of southeastern Brazil. J. Vector Ecol. 40(1): 28-35.

WILKERSON, R.C., LINTON, Y.-M., FONSECA, D.M., SCHULTZ, T.R., PRICE, D.C. \& STRICKMAN, D.A. 2015. Making mosquito taxonomy useful: A stable classification of tribe Aedini that balances utility with current knowledge of evolutionary relationships. Plos one | DOI: 10.1371/journal.pone.0133602.

Received: $15 / 08 / 2016$

Revised: 15/12/2016

Accepted: 23/12/2017

Published online: 22/01/2018 